\title{
ANALYSIS OF THE NORMAL TENSION VALUES IN THE CONTACT ZONE AND ON THE FILLETS OF THE BASIC TOOTHED GEAR PAIRS AS A FUNCTION OF THE CHANGE OF THE MODULE
}

\author{
S. BODZÁS
}

Department of Mechanical Engineering, University of Debrecen, H-4028 Debrecen, Ótemető u. 2-4, Hungary

E-mail: bodzassandor@eng.unideb.hu

In our publication, more than one basic toothed gear pairs have been designed and modelled. Normal tension dispersions - appearing in the contact zone of the drive pair - and their measure on contact tooth surfaces have been analyzed by the effect of a given moment load. During designing the numbers of the teeth of the gear pairs have been chosen equal, but the modules of the pairs have been different. We analyze how normal tension values form on the tooth surfaces of the gears in the contact zone of the tooth and on their root zone as a function of the change of the module in the case of the same meshing method, loads and boundary conditions.

Keywords: basic toothing, finite element method (FEM), normal tension, module

\section{Introduction}

A certain computer program was developed for making the CAD models [1-6] of the basic toothed gear pairs. Input values of the program are the number of

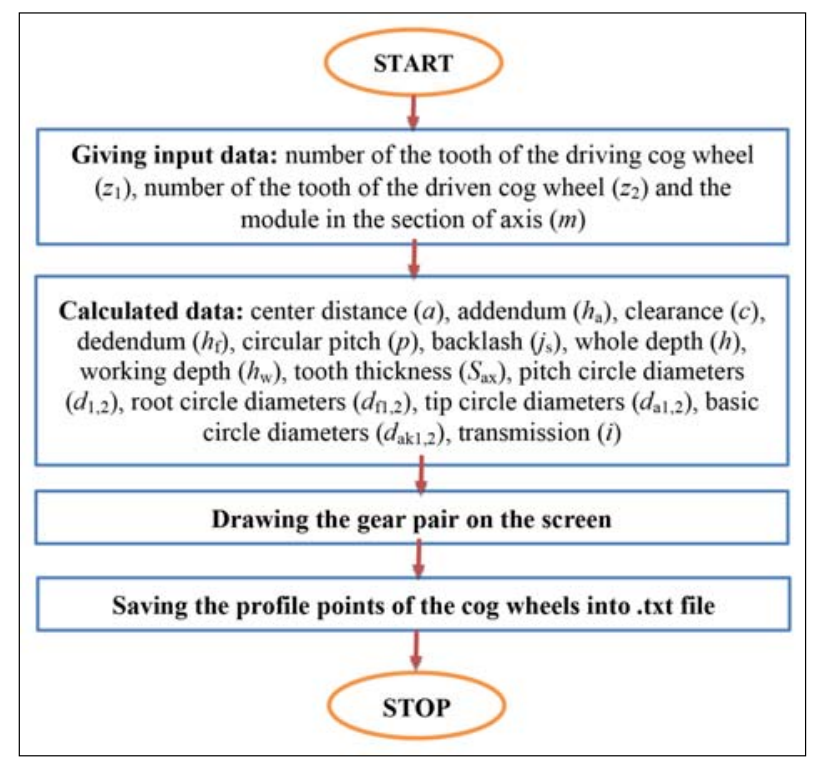

Fig. 1. The principle of the operation of the program teeth $\left(z_{1}\right.$ and $\left.z_{2}\right)$ and the module $(m)$ of the driving and driven cog wheels (Fig. 1).

Based on the input parameters, the program calculates the further parameters of the gear pairs and it draws the $\operatorname{cog}$ wheels on the screen. It saves the profile points of the cog wheel in .txt file, which can be imported in SolidWorks design software. After all these CAD models of the given gear pairs can be made. Table 1 contains those parameters of the gear pairs which were designed by us.

During designing the numbers of the teeth of the $\operatorname{cog}$ wheels on the driving and the driven gears were chosen equal but we enhanced the value of the module (Table 1).

\section{Making the mesh of FEM}

For the analysis of the contact points, Ansys R18.0 FEM software was used. In the tooth contact zone, 0.15 frictional factor was applied. During the CAD modelling of the cog wheels, between the root circle diameter and the inner diameters of the bore, $15 \mathrm{~mm}$ thickness was applied in the case of every cog wheel. The tooth length of the cog wheels was chosen to be $40 \mathrm{~mm}$ each.

\footnotetext{
This is an open-access article distributed under the terms of the Creative Commons Attribution-NonCommercial 4.0 International License (https://creativecommons.org/licenses/by-nc/4.0/), which permits unrestricted use, distribution, and reproduction in any medium for non-commercial purposes, provided the original author and source are credited, a link to the CC License is provided, and changes - if any - are indicated.
} 
Table 1. The parameters of the designed drive pairs

\begin{tabular}{|c|c|c|c|c|c|}
\hline Parameters & Gear drive I & Gear drive II & Gear drive III & Gear drive III & Gear drive IV \\
\hline Axial module $(m)[\mathrm{mm}]$ & 5 & 8 & 12 & 18 & 25 \\
\hline $\begin{array}{l}\text { Number of tooth of the } \\
\text { driving gear }\left(z_{1}\right)\end{array}$ & 25 & 25 & 25 & 25 & 25 \\
\hline $\begin{array}{l}\text { Number of tooth of the } \\
\text { driven gear }\left(z_{2}\right)\end{array}$ & 35 & 35 & 35 & 35 & 35 \\
\hline Centre distance $(a)[\mathrm{mm}]$ & 150 & 240 & 360 & 540 & 750 \\
\hline Addendum $\left(h_{\mathrm{a}}\right)[\mathrm{mm}]$ & 5 & 8 & 12 & 18 & 25 \\
\hline Clearance $(c)[\mathrm{mm}]$ & 1.25 & 2 & 3 & 4.5 & 6.25 \\
\hline Dedendum $\left(h_{\mathrm{f}}\right)[\mathrm{mm}]$ & 6.25 & 10 & 15 & 22.5 & 31.25 \\
\hline Circular pitch $(p)[\mathrm{mm}]$ & 15.708 & 25.132 & 37.699 & 56.548 & 78.539 \\
\hline $\operatorname{Backlash}\left(j_{\mathrm{s}}\right)[\mathrm{mm}]$ & 0.785 & 1.256 & 1.885 & 2.827 & 3.927 \\
\hline Whole depth $(h)[\mathrm{mm}]$ & 11.25 & 18 & 27 & 40.5 & 56.25 \\
\hline Working depth $\left(h_{\mathrm{w}}\right)[\mathrm{mm}]$ & 10 & 16 & 24 & 36 & 50 \\
\hline Tooth thickness $\left(S_{\mathrm{ax}}\right)[\mathrm{mm}]$ & 7.461 & 11.938 & 17.907 & 26.86 & 37.306 \\
\hline $\begin{array}{l}\text { Pitch circle diameter of the } \\
\text { driving gear }\left(d_{1}\right)[\mathrm{mm}]\end{array}$ & 125 & 200 & 300 & 450 & 625 \\
\hline $\begin{array}{l}\text { Tip circle diameter of the } \\
\text { driving gear }\left(d_{\mathrm{a} 1}\right)[\mathrm{mm}]\end{array}$ & 135 & 216 & 324 & 486 & 675 \\
\hline $\begin{array}{l}\text { Root circle diameter of the } \\
\text { driving gear }\left(d_{\mathrm{f} 1}\right)[\mathrm{mm}]\end{array}$ & 112.5 & 180 & 270 & 405 & 562.5 \\
\hline $\begin{array}{l}\text { Basic circle diameter of the } \\
\text { driving gear }\left(d_{\mathrm{ak} 1}\right)[\mathrm{mm}]\end{array}$ & 117.461 & 187.938 & 281.907 & 422.861 & 587.307 \\
\hline $\begin{array}{l}\text { Pitch circle diameter of the } \\
\text { driven gear }\left(d_{2}\right)[\mathrm{mm}]\end{array}$ & 175 & 280 & 420 & 630 & 875 \\
\hline $\begin{array}{l}\text { Tip circle diameter of the } \\
\text { driven gear }\left(d_{\mathrm{a} 2}\right)[\mathrm{mm}]\end{array}$ & 185 & 296 & 444 & 666 & 925 \\
\hline $\begin{array}{l}\text { Root circle diameter of the } \\
\text { driven gear }\left(d_{\mathrm{f} 2}\right)[\mathrm{mm}]\end{array}$ & 162.5 & 260 & 390 & 585 & 812.5 \\
\hline $\begin{array}{l}\text { Basic circle diameter of the } \\
\text { driven gear }\left(d_{\mathrm{ak} 2}\right)[\mathrm{mm}]\end{array}$ & 164.446 & 263.113 & 394.67 & 592.006 & 822.231 \\
\hline Transmission $(i)$ & 1.4 & 1.4 & 1.4 & 1.4 & 1.4 \\
\hline
\end{tabular}

During the calculations tetrahedron meshing was applied on the face surfaces, while tooth lengths were divided into 10 equal parts $[5,9]$. The density of the meshing was automatic outside the tooth contact zone $[5,9]$. Inside the tooth contact zone $1 \mathrm{~mm}$ density meshing was applied (Fig. 2).

\section{Setting the loads and boundary conditions}

During the analysis, the material of the drive pairs was structural steel (Table 2). The driving cog wheel $\left(z_{1}=\right.$ 25) was loaded by $40 \mathrm{Nm}$ torque (Fig. 3).

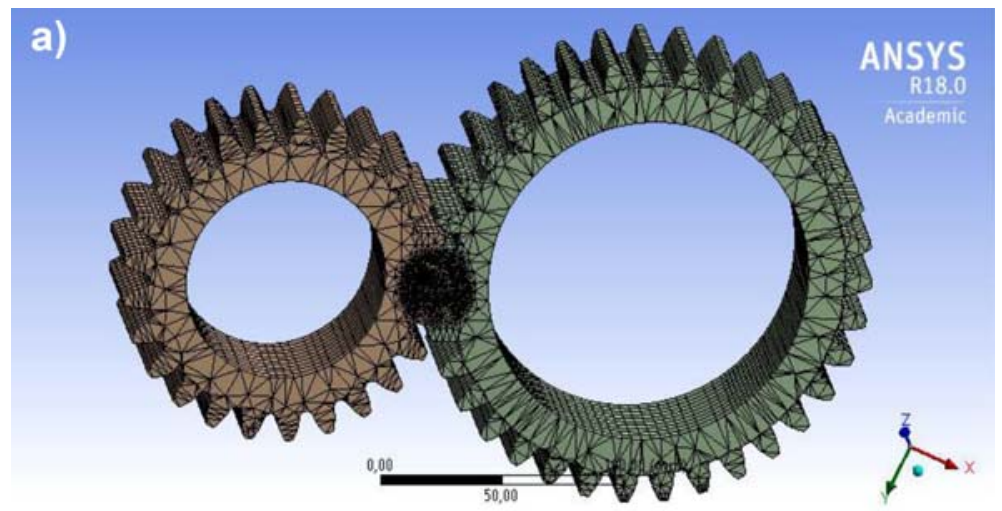

Fig. 2. Application of the mesh of FEM 


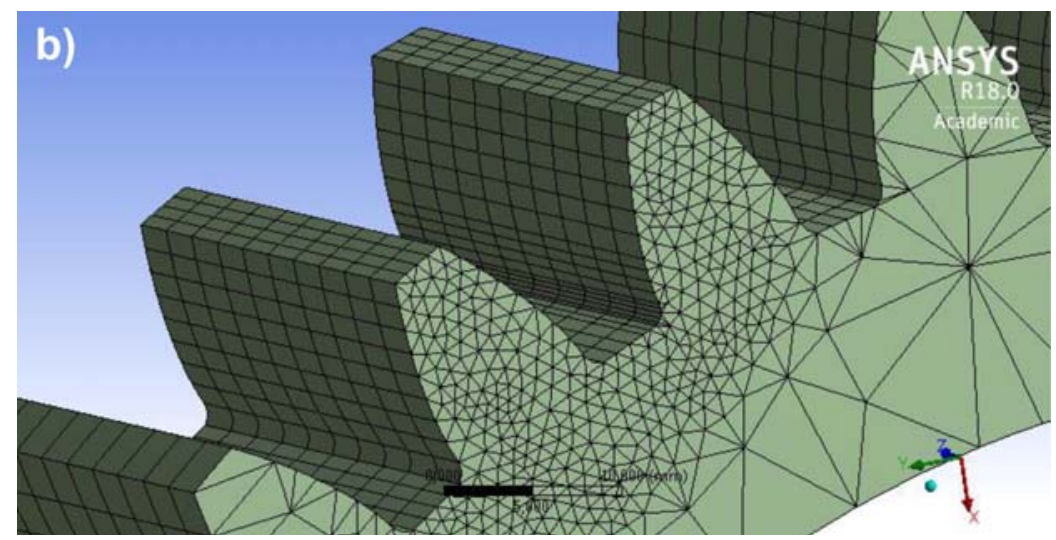

Fig. 2. cont'd

Table 2. Parameters of the material

\begin{tabular}{ll}
\hline Density & $7850 \mathrm{~kg} / \mathrm{m}^{3}$ \\
Yield limit & $250 \mathrm{MPa}$ \\
Ultimate strength & $460 \mathrm{MPa}$ \\
\hline
\end{tabular}

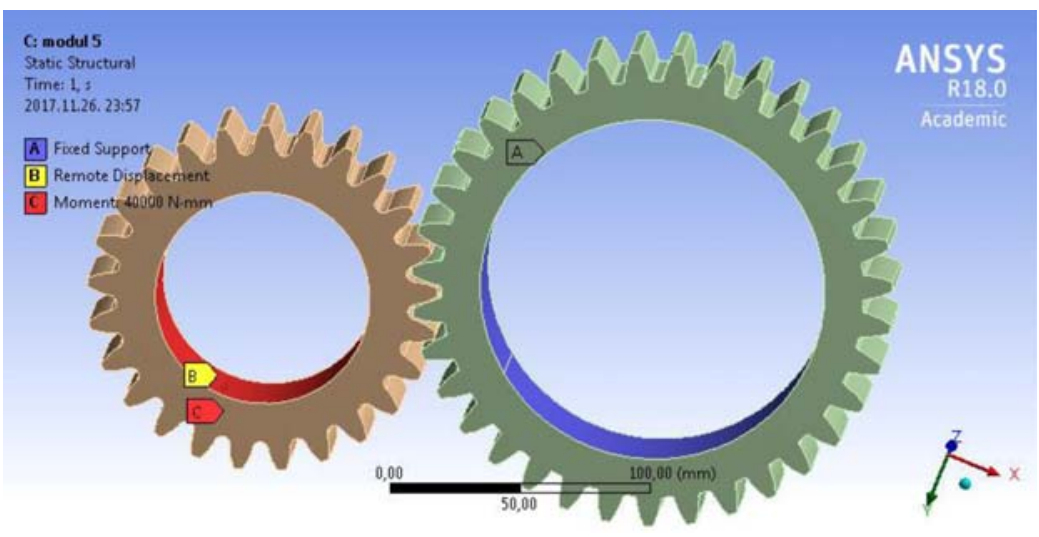

Fig. 3. Setting the loads and boundary conditions

Five degrees of freedom of the driving $\operatorname{cog}$ wheel were fixed. Only the rotational movement around the rotational shaft was allowed. In the case of the driven cog wheel fixed support was applied (Fig. 3) [5, 7-9].

\section{Normal tension analyses in the contact zone}

Figure 4 shows normal tension dispersions - on the driving gear contact tooth surfaces - which are the

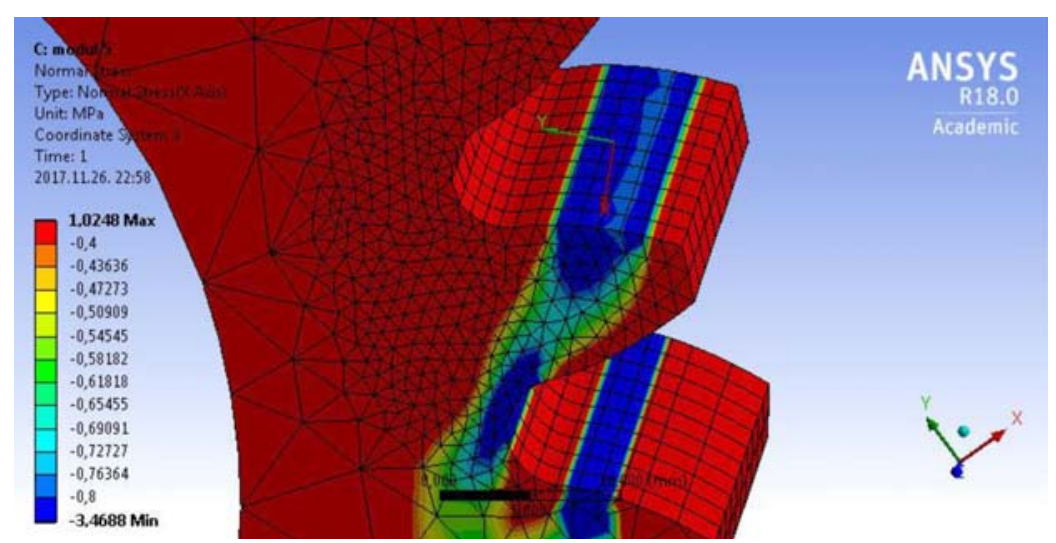

Fig. 4a. In case of $5 \mathrm{~mm}$ module (average normal tension on the tooth surface: $-1.057 \mathrm{MPa}$ ) 


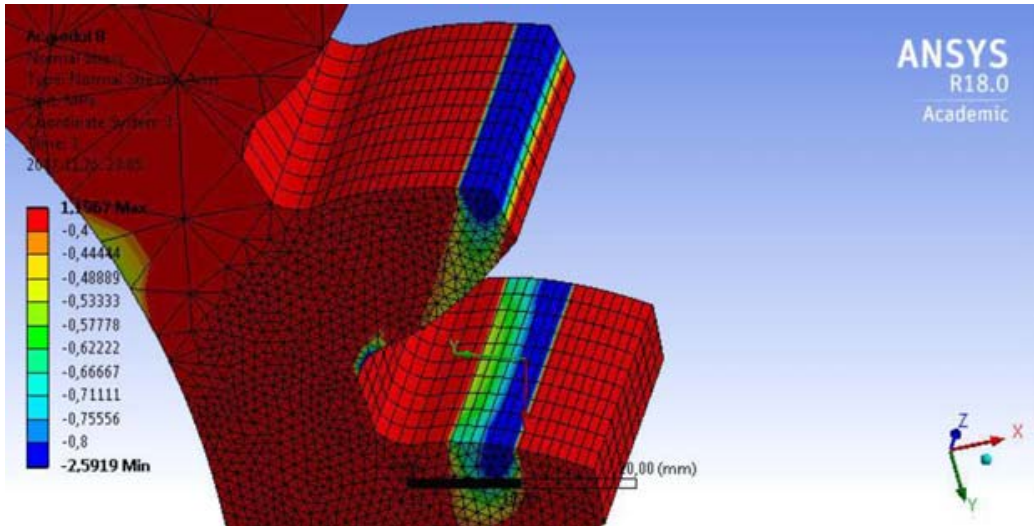

Fig. 4b. In case of $8 \mathrm{~mm}$ module (average normal tension on the tooth surface: $-0.873 \mathrm{MPa}$ )

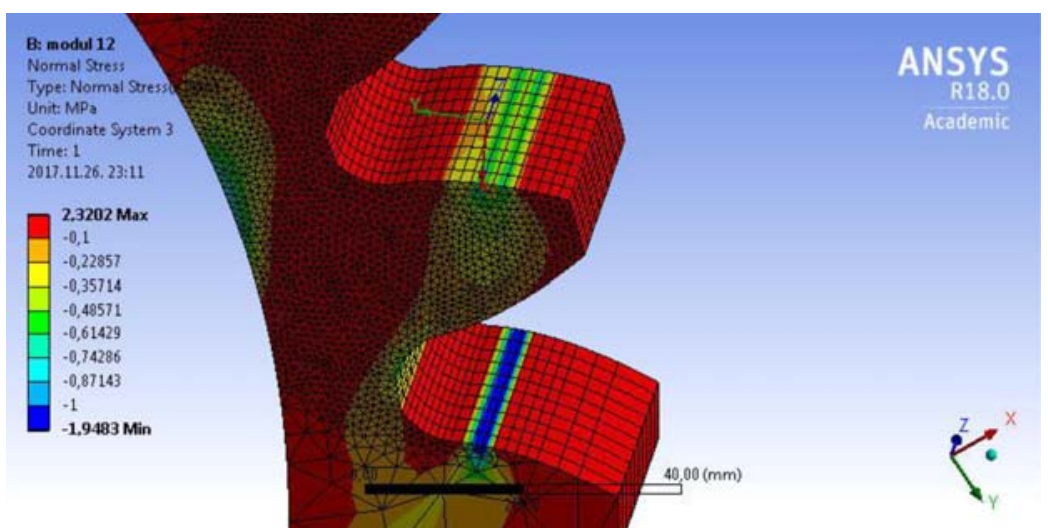

Fig. 4c. In case of $12 \mathrm{~mm}$ module (average normal tension on the tooth surface: $-0.642 \mathrm{MPa}$ )

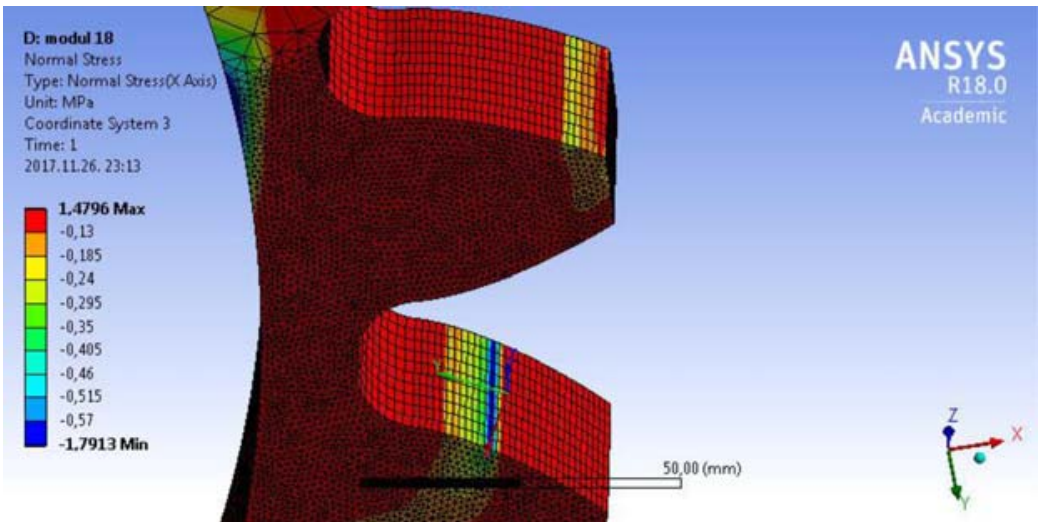

Fig. 4d. In case of $18 \mathrm{~mm}$ module (average normal tension on the tooth surface: $-0.243 \mathrm{MPa}$ )

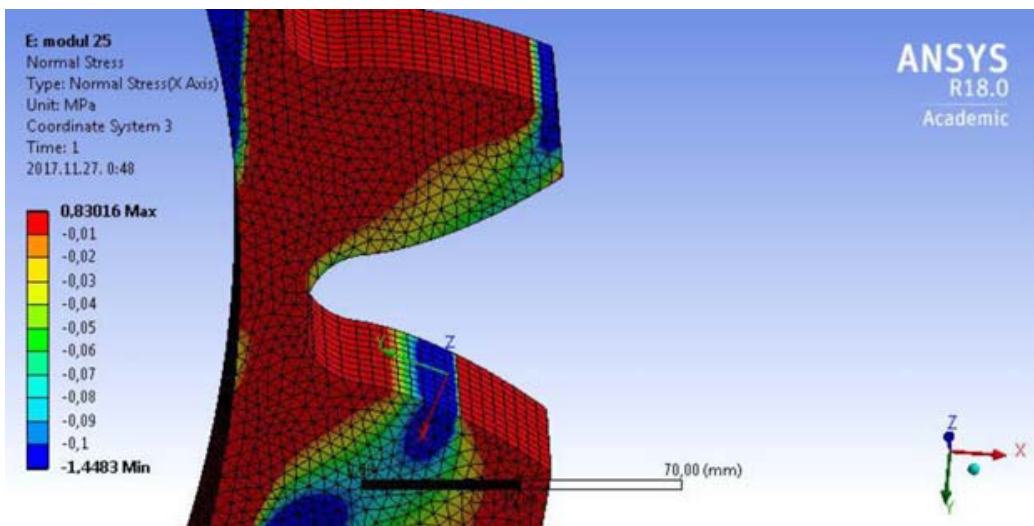

Fig. 4e. In case of $25 \mathrm{~mm}$ module (average normal tension on the tooth surface: $-0.143 \mathrm{MPa}$ ). Normal tension values on the tooth surfaces of the driving cog wheel 
effect of the load of $40 \mathrm{Nm}$ torque. Based on Fig. 4 , it can be stated that on the tooth surfaces of the driving $\operatorname{cog}$ wheels in the contact zone, perpendicular to the tooth surface, the values of the normal tension decrease as a function of enhancing the value of the module.

Figure 5 shows normal tension dispersions - on the contact tooth surfaces of the driving $\operatorname{cog}$ wheels - as an effect of the $40 \mathrm{Nm}$ load of torque. Based on Fig. 5 , it can be stated that on the tooth surfaces of the driven $\operatorname{cog}$ wheels in the contact zone, perpendicular to the tooth surface, the values of the normal tension decrease as a function of enhancing the value of the module.

\section{Normal tension analyses on the fillet}

As an effect of the moment, on the fillet radius of the contact teeth those tension values are formed as shown in Fig. 6. The tension analysis of the fillet (root of the tooth) is important because of the bending stress and of any accidental tooth break.

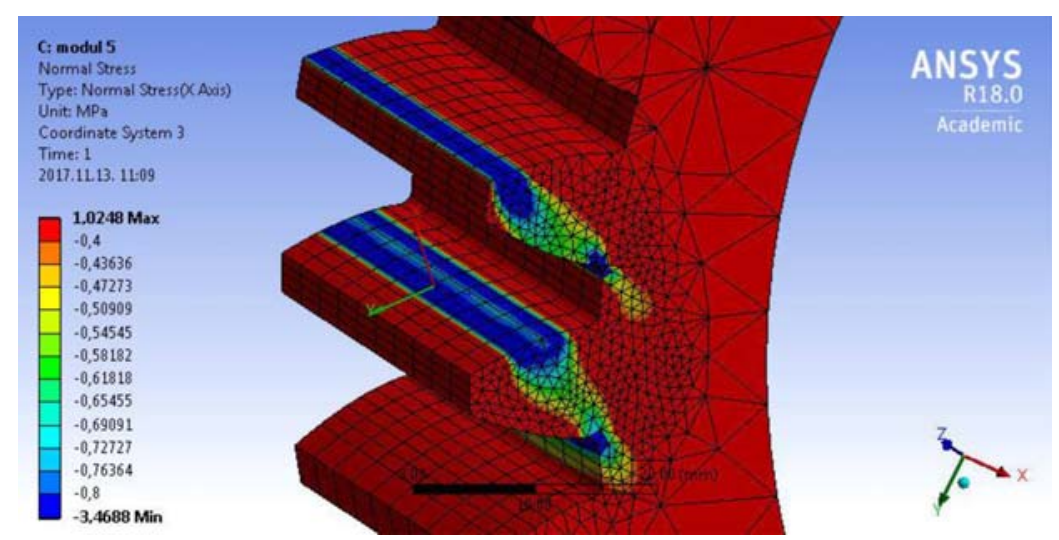

Fig. 5a. In case of $5 \mathrm{~mm}$ module (average normal tension on the tooth surface: $-1.022 \mathrm{MPa}$ )

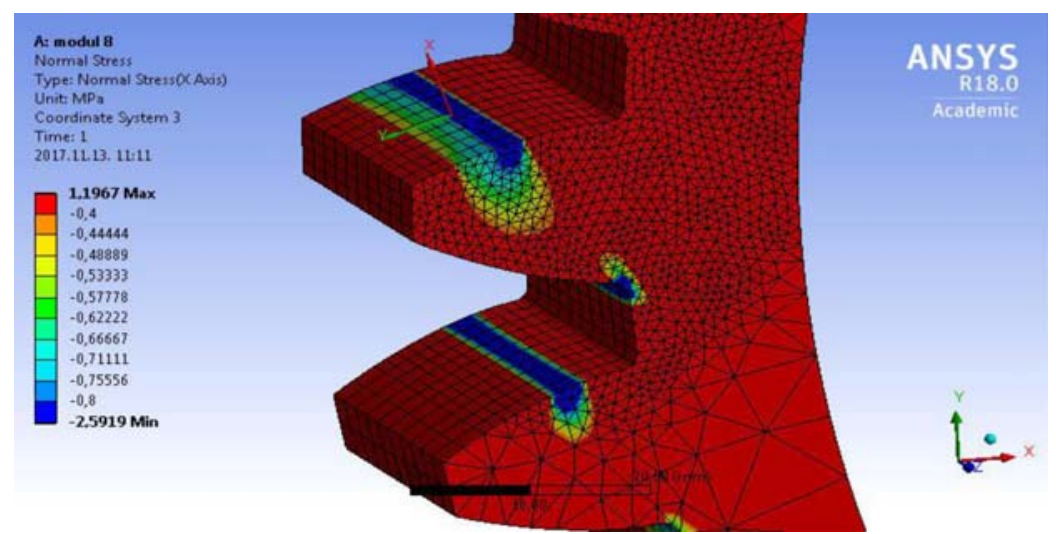

Fig. 5b. In case of $8 \mathrm{~mm}$ module (average normal tension on the tooth surface: $-0.834 \mathrm{MPa}$ )

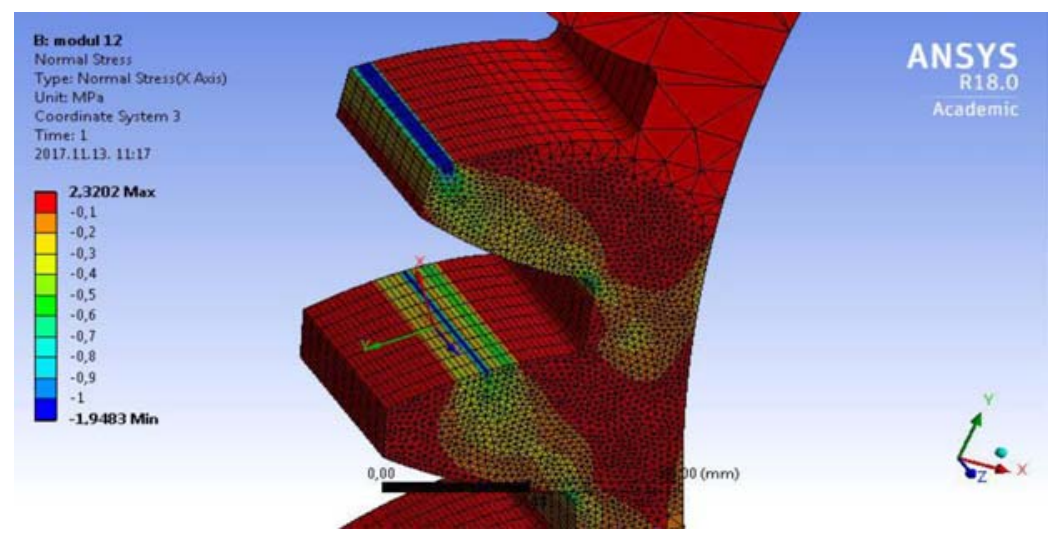

Fig. 5c. In case of $12 \mathrm{~mm}$ module (average normal tension on the tooth surface: $-0.739 \mathrm{MPa}$ ) 


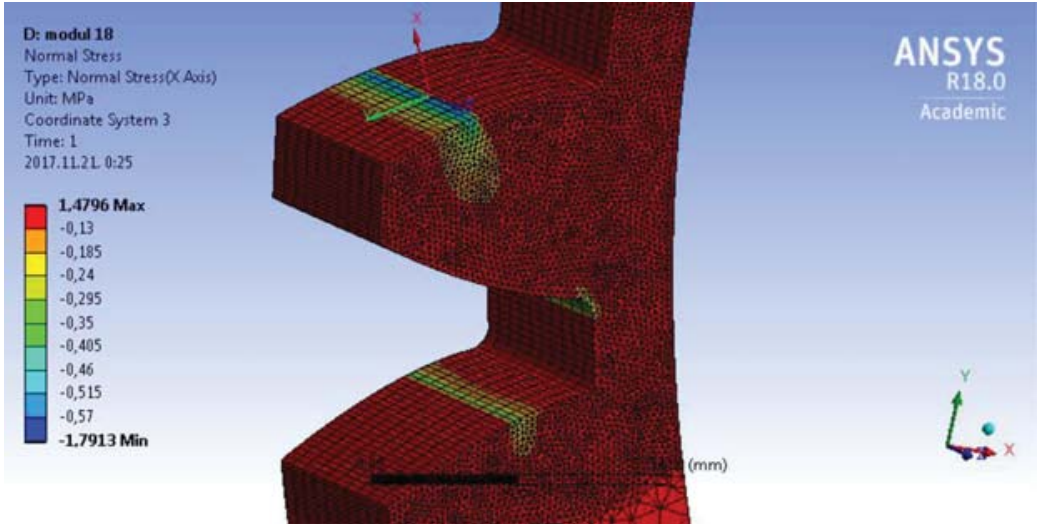

Fig. 5d. In case of $18 \mathrm{~mm}$ module (average normal tension on the tooth surface: $-0.295 \mathrm{MPa}$ )

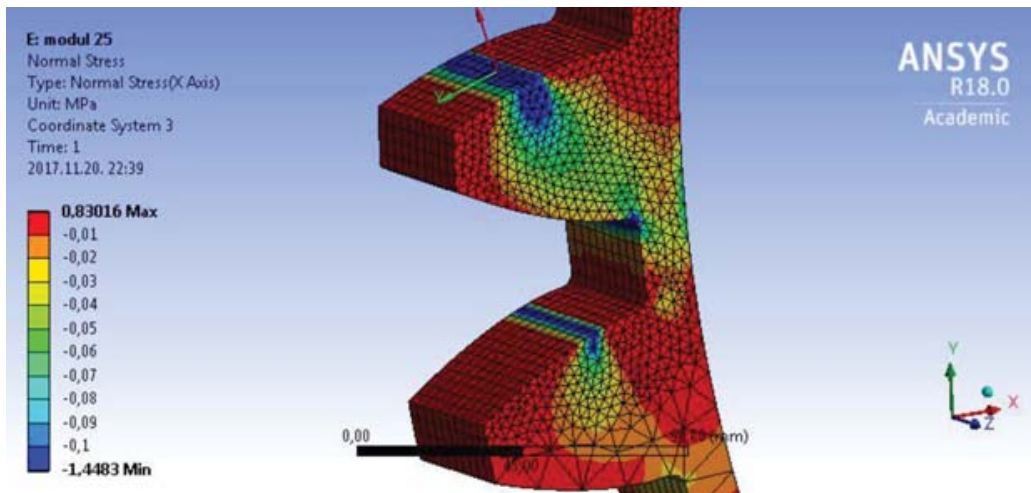

Fig. 5e. In case of $25 \mathrm{~mm}$ module (average normal tension on the tooth surface: $-0.136 \mathrm{MPa}$ ). Normal tension values on the tooth surfaces of the driven cog wheel

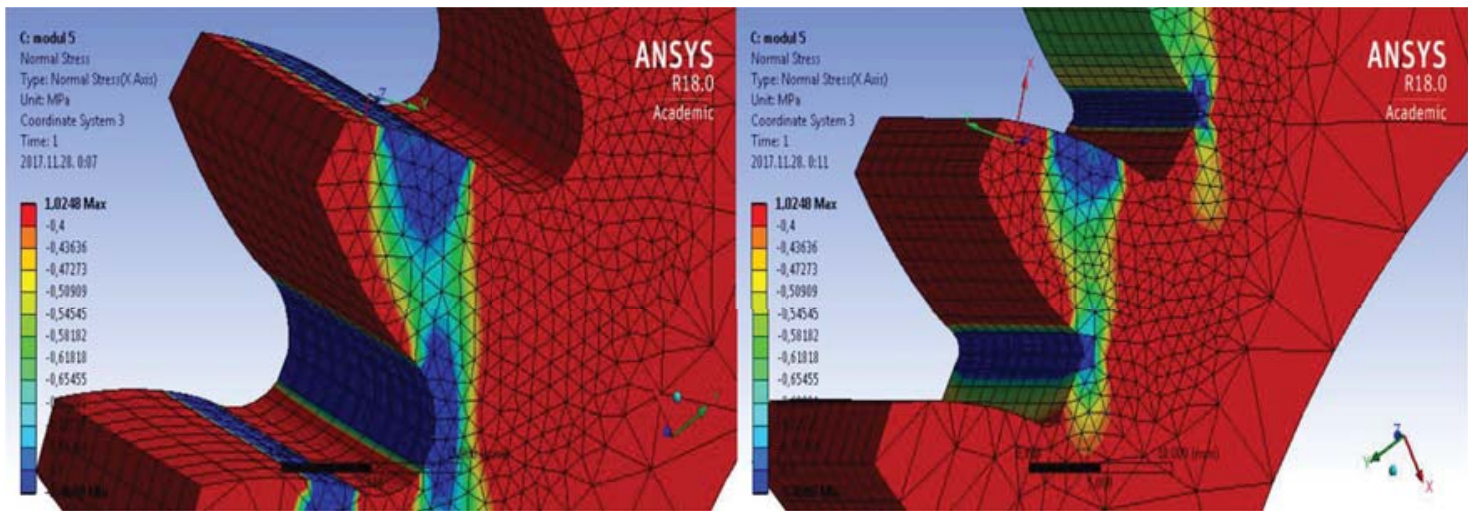

Fig. 6a. In case of $5 \mathrm{~mm}$ module, the driving and driven $\operatorname{cog}$ wheels

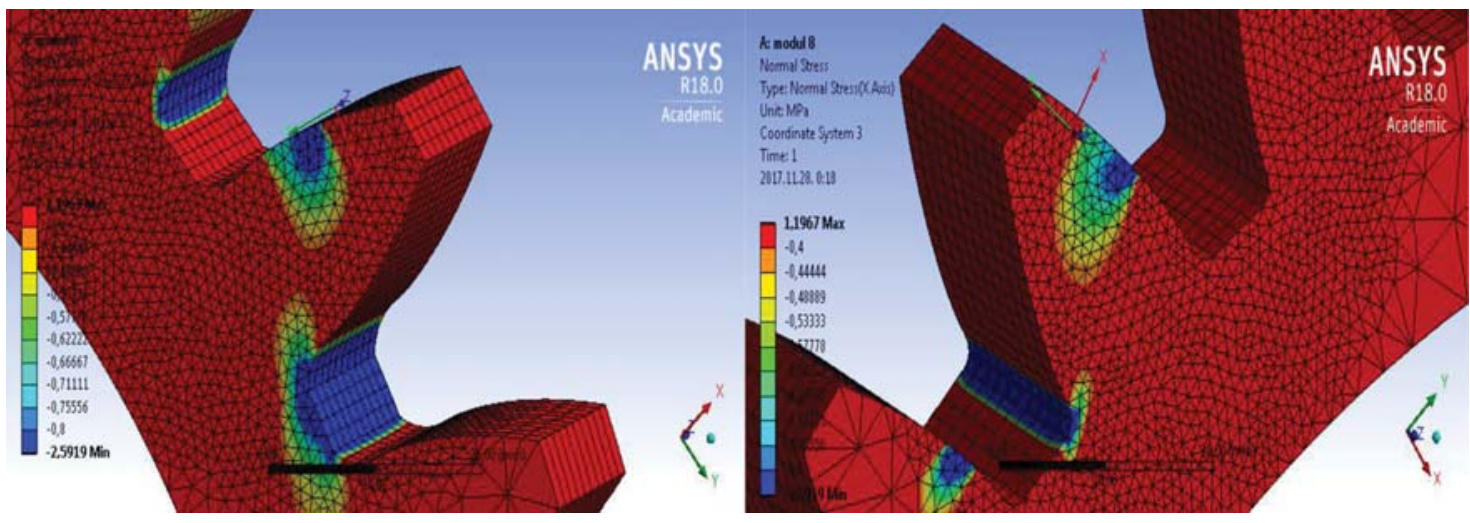

Fig. 6b. In case of $8 \mathrm{~mm}$ module, the driving and driven $\operatorname{cog}$ wheels 


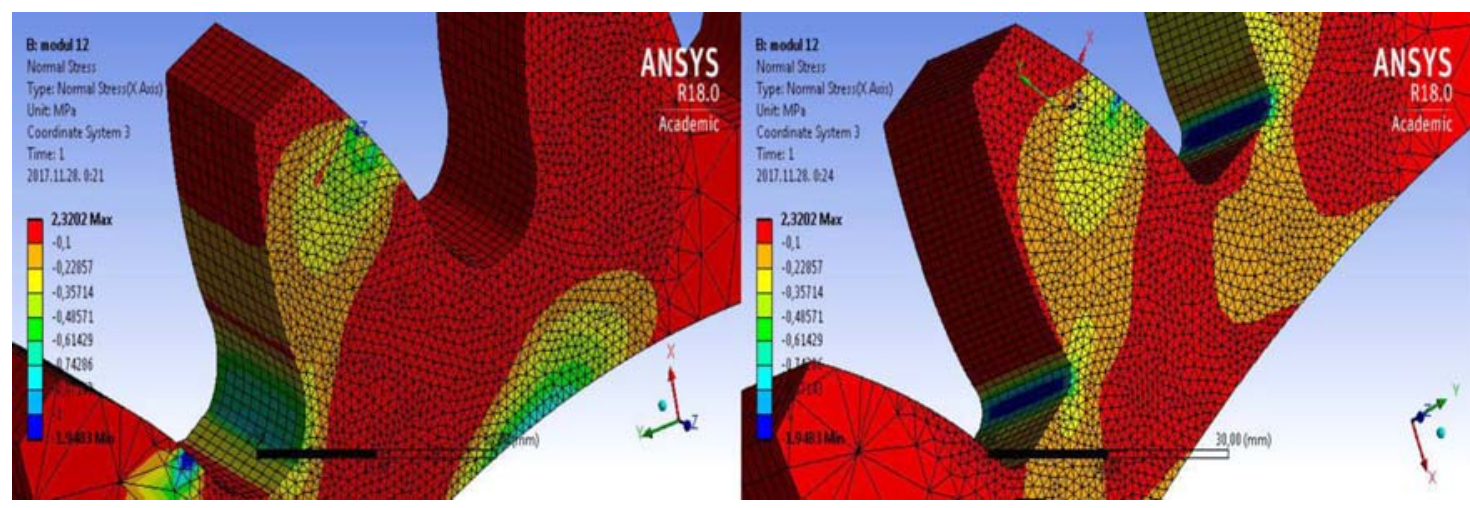

Fig. 6c. In case of $12 \mathrm{~mm}$ module, the driving and driven cog wheels

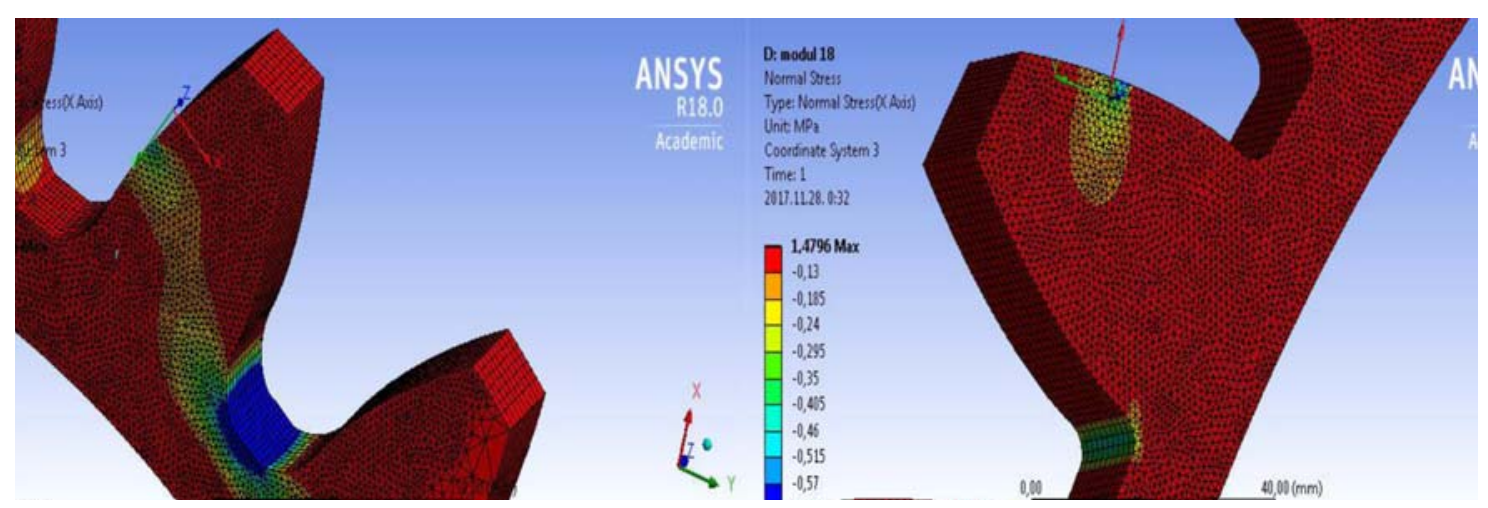

Fig. 6d. In case of $18 \mathrm{~mm}$ module, the driving and driven cog wheels

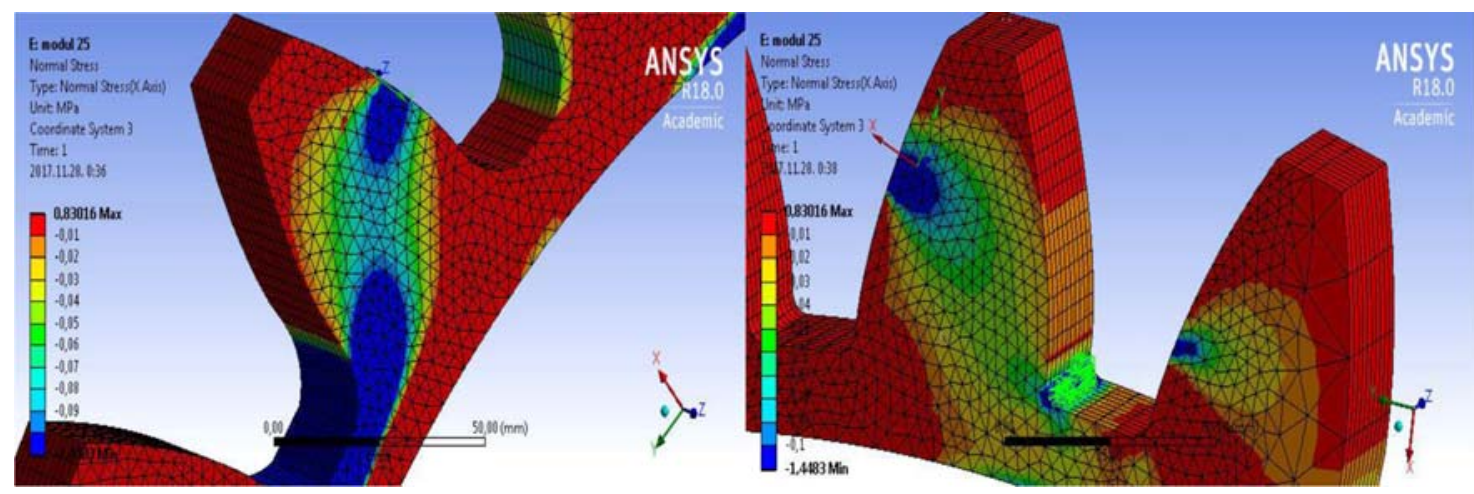

Fig. 6e. In case of $25 \mathrm{~mm}$ module, the driving and driven $\operatorname{cog}$ wheels. Normal tension values occurring in the fillet of $\operatorname{cog}$ wheels

Figure 6 shows that normal tension values in the fillet of the contact cog pairs decrease in the way perpendicular to the surface, as a function of enhancing the module.

\section{Summary}

A computer program has been developed to ease the designing and modelling of basic toothed gear pairs. The CAD models of the gear pairs (with equal num- ber of tooth, but different modules) have been made in Solidworks design software.

The Ansys Finite Element Method (FEM) software has been used to analyze the normal tension values as an effect of the load - on the tooth surfaces of the driving and driven cog wheels. During the analyses, the cog wheels having less number of teeth have been the driving cog wheels. On the face surfaces tetrahedron meshing has been applied, while on the tooth surfaces we applied 10 equally divided mesh - along the tooth length. 
After setting the load and the boundary conditions we got the result that as a function of enhancing the module, on the contact tooth surfaces and fillets of the driving and driven gear pairs - in the contact zone - normal tension values perpendicular to the surface decrease.

\section{Acknowledgements}

This research was supported by the János Bolyai Research Scholarship of the Hungarian Academy of Sciences.

\section{References}

[1] Bodzás S. (2017), Computer aided designing and modelling of x-zero gear drive. International Review of Applied Sciences and Engineering, 8(1), 93-97.

[2] Dudás I. (2011), Gépgyártástechnológia III., A. Megmunkáló eljárások és szerszámaik, B. Fogazott alkatrészek gyártása és szerszámaik. Műszaki Kiadó, Budapest
[3] Dudás L. (1991), Kapcsolódó felületpárok gyártásgeometriai feladatainak megoldása az elérés modell alapján. Kandidátusi Tézisek, Budapest, TMB, p. 144.

[4] Erney Gy. (1983), Fogaskerekek. Müszaki Könyvkiadó, Budapest, p. 460

[5] Litvin F. L., Fuentes A. (2004), Gear Geometry and Applied Theory. Cambridge University Press, ISBN 9780 521815178

[6] Terplán Z. (1975), Gépelemek IV. Kézirat, Tankönyvkiadó, Budapest, p. 220

[7] Páczelt I., Szabó T., Baksa A., A végeselem módszer alapjai. Értékünk az ember, Humánerőforrás fejlesztési Operatív Program, Miskolci Egyetemi Elektronikus jegyzet

[8] Szabó F., Bihari Z., Sarka F. (2006), Termékek, szerkezetek, gépelemek végeselemes modellezés és optimálása. Szakmérnöki jegyzet, Miskolc

[9] Litvin F. L., Fuentes A., Fan Q., Handschuh R. H. (2002), Computerized Design, Simulation of Meshing, and Contact and Stress Analysis of Face-Milled Formate Generated Spiral Bevel Gears. In: Mechanism and Machine Theory, Elsevier, pp. 441-459 